\title{
ANALISIS FRAMING PEMBERITAAN GENERASI MILENIAL TERKAIT PROMOSI PARIWISATA SELAMA PANDEMI COVID-19 PADA MEDIA ONLINE
}

\author{
I Made Surya Prayoga \\ Program Studi Manajemen,Universitas Maha Saraswati, \\ Denpasar, Indonesia \\ prayogamade@unmas.ac.id
}

\begin{abstract}
ABSTRAK
Penelitian ini bertujuan untuk mengidentifikasi pemberitaan media online mengenai peran generasi milenial terkait promosi pariwisata selama pandemi covid-19. Genarasi milenial merupakan generasi yang sangat potensial karena kemampuanya dalam mengadopsi teknologi yang diharapkan dapat membantu memulihkan kondisi industri pariwisata yang tengah terpuruk akibat wabah covid19 melalui promosi pariwisata yang berbasis teknologi atau digital marketing. Penelitian ini menggunakan metode analisis framing Robert N. Entman dengan pendekatan kualitatif. Empat tahap Framing Entmant mencakup: define problem, diagnose cause, make moral judgment dan treatment recommendation. Hasil penelitian ini juga menunjukan beberapa hal penting diantaranya adalah define problem yaitu belum optimalnya peran generasi milenial sebagai ujung tombak dalam promosi pariwisata di Indonesia. Diagnose cause yaitu belum optimalnya peran generasi milenial akan menyebabkan industri pariwisata kian lesu dan tidak dapat bangkit dari keterpurukaan keadaan saat pandemi covid-19. Make moral judgment dimana pihak pemerintah berusaha memberikan pelatihan-pelatihan serta penguatan guna mempertegas peran dan fungsi generasi milenial sebagai ujung tombak di dalam promosi pariwisata di Indonesia. Treatment recommendations yaitu penting bagi semua pihak untuk mendukung penuh generasi milenial dalam mempromosikan pariwisata, kemampuan dari karakteristik generasi milenial yang sangat mudah mengadopsi teknologi baru, diharapakan dapat mempermudah generasi milenial dalam memaksimalkan setiap peluang guna mempromosikan wisata Indonesia ke seluruh pelosok dunia di era new normal. Melalui temuan penelitian ini diharapkan media online mampu membantu pemerintah menyampaikan pesan dan pemberitaan positif sehingga mampu tetap menumbuhkan optimisme di tengah masyarkat.
\end{abstract}

Kata kunci : analisis framing, generasi milenial, promosi pariwisata, covid-19.

\begin{abstract}
This study aims to identify online media coverage of the role of the millennial generation in relation to tourism promotion during the Covid-19 pandemic. The millennial generation is a generation with great potential because of its ability to adopt technology that is expected to help restore the condition of the tourism industry which is currently deteriorating due to the Covid-19 outbreak through technology-based tourism promotion or digital marketing. This study uses the Robert N. Entman framing analysis method with a qualitative approach. The four stages of Framing Entmant include: define problems, diagnose causes, make moral judgment and treatment recommendation. The results of this study also show several important things, including define the problem, namely
\end{abstract}


the not optimal role of the millennial generation as the spearhead of tourism promotion in Indonesia. Diagnose cause, namely the not optimal role of the millennial generation will cause the tourism industry to become increasingly sluggish and unable to rise from the downturn of the situation during the Covid-19 pandemic. Make moral judgment where the government tries to provide training and strengthening to reinforce the role and function of the millennial generation as the spearhead in tourism promotion in Indonesia. Treatment recommendations are important for all parties to fully support the millennial generation in promoting tourism, the ability of the characteristics of the millennial generation who are very easy to adopt new technology, is hoped to make it easier for the millennial generation to maximize every opportunity to promote Indonesian tourism to all corners of the world in the new normal era. Through the findings of this study, it is hoped that online media will be able to help the government convey positive messages and news so that it is able to continue to foster optimism in the community.

Keywords: framing analysis, millennial generation, tourism promotion, covid-19

\section{PENDAHULUAN}

Pariwisata merupakan salah satu sektor industri yang mampu menghasilkan perubahan ekonomi yang cepat dalam menyediakan lapangan kerja, meningkatkan pendapatan penghasilan pemerintah dan masyarakat. Standar hidup serta meningkatkan sektor-sektor produktifitas lainnya. Industri pariwisata mempunyai dampak dan manfaat yang banyak, di antaranya selain menghasilkan devisa negara, sektor pariwisata bertujuan untuk menjaga kelestarian alam dan mengembangkan budaya lokal. Dalam kurun waktu sepuluh tahun terakhir tahun 2009-2019, pariwisata dunia terus mengalami peningkatan. Wisatawan internasional (international tourist) meningkat dari 892 juta orang pada saat masa krisis tahun 2009 menjadi 1.461 juta orang pada tahun 2019. Indikator kinerja lain menunjukkan nilai strategis dari pariwisata dunia tahun 2019 antara lain: pertumbuhan 4\%; satu dari sepuluh lapangan kerja di dunia diisi pekerja dari sektor pariwisata; berkontribusi $7 \%$ dari ekspor global (UNWTO dalam Sugihamretha, 2020). Tekanan pada industri pariwisata sangat terlihat pada penurunan yang besar dari kedatangan wisatawan mancanegara dengan pembatalan besar-besaran dan penurunan pemesanan. Penurunan juga terjadi karena perlambatan perjalanan domestik, terutama karena keengganan masyarakat Indonesia untuk melakukan perjalanan, khawatir dengan dampak Covid-19. Penurunan bisnis pariwisata dan perjalanan berdampak pada usaha UMKM, dan terganggunya lapangan kerja. Padahal selama ini pariwisata merupakan sektor padat karya yang menyerap lebih dari 13 juta pekerja. Angka itu belum termasuk dampak turunan atau multiplier effect yang mengikuti termasuk industri turunan yang terbentuk di bawahnya. (Sugihamretha, 2020). Multplier effect adalah proses yang menunjukkan sejauh mana pendapatan nasional akan berubah efek dari perubahan dalam pengeluaran agregat. Multiplier bertujuan untuk menerangkan pengaruh dari kenaikan atau kemerosotan dalam pengeluaran agregat ke atas tingkat keseimbangan dan terutama ke atas tingkat pendapatan nasional. Keunikan industri pariwisata terhadap perekonomian berupa dampak ganda (multiplier effect) dari pariwisata terhadap ekonomi Putra, et al (2017). 
Pariwisata memberikan pengaruh tidak hanya terhadap sektor ekonomi yang langsung terkait dengan industri pariwisata, tetapi juga industri yang tidak langsung terkait dengan industri pariwisata. Analisis dampak ekonomi kegiatan wisata terkait dengan elemen-elemen penghasilan, penjualan dan tenaga kerja di daerah kawasan wisata yang terjadi akibat kegiatan pariwisata.

Di Indonesia pariwisata merupakan salah satu daya saing negara di kancah dunia, peringkat daya saing pariwisata Indonesia dalam Travel and Tourism Competitiveness Index dari tahun ke tahun memang semakin baik. Tercatat, pada 2015 Indonesia berada pada peringkat 50, kemudian naik menjadi peringkat ke-42 pada 2017, dan naik lagi menjadi peringkat ke-40 pada 2019 (Pikiran rakyat.com, 2020). Bahkan di tahun 2021 Menteri Pariwisata dan Ekonomi Kreatif Wishnutama Kusubandio menargetkan peringkat indeks pariwisata Indonesia naik. Penilaian yang dilakukan secara sebelumnya mencatat Indonesia pada peringkat 40 di tahun 2019. Targetnya tahun 2021 mendatang Indonesia mampu berada pada peringkat 36 hingga 38 (Nasional.kontan.co.id, 2020).

Perencanaan pemerintah Indonesia dalam pengembangan pariwisata yang sudah di susun dengan sistematis dan terstruktur dengan jelas dihadapkan pada suatu hambatan yang sangat besar, yaitu pandemi covid-19. Severe acute respiratory syndrome coronavirus 2 (SARS-CoV-2) yang lebih dikenal dengan nama virus Corona pertama kali ditemukan di kota Wuhan, China pada akhir Desember 2019. Virus ini menular dengan sangat cepat dan telah menyebar ke hampir semua negara, termasuk Indonesia, hanya dalam waktu beberapa bulan. Menurut data yang dirilis Gugus Tugas Percepatan Penanganan Covid-19 Republik Indonesia, jumlah kasus terkonfirmasi positif hingga 28 Oktober 2020 adalah 396.454 orang dengan jumlah kematian 13.512 orang. Tingkat kematian (case fatality rate) akibat Covid-19 adalah sekitar 3,4\%, kelompok usia di atas 60 tahun memiliki persentase angka kematian yang lebih tinggi dibandingkan golongan usia lainnya Sedangkan berdasarkan jenis kelamin, 58,5\% penderita yang meninggal akibat Covid-19 adalah laki-laki dan 41,5\% sisanya adalah perempuan (Alodokter.com, 2020) Dalam mengantisipasi pandemic Covid-19, pemerintah Indonesia melakukan berbagai kebijakan terkait pencegahan Covid-19, diantaranya himbauan social distancing, protokol kesehatan, Pembatasan Sosial Berskala Besar (PSSB) dan himbauan "dirumahaja" sebagai jargon agar masyarakat untuk sementara wakktu melakukan aktivitas bekerja, belajar dan beribadah dari rumah saja. Kebijakan ini merupakan langkah awal yang dilakukan dengan merujuk negara lain yang telah terlebih dahulu terkena wabah Covid-19. Cina misalnya yang mengambil langkah karantina total atau lockdown pada Januari 2020. Kebijakan lockdown dinilai efektif dalam mengurangi penyebaran Covid-19 dan oleh karenanya sekitar 15 negara memberlakukan kebijakan yang sama yakni di Italia, Spanyol, Perancis, Irlandia, Belgia, Malaysia, Filipina dan lainnya.

Keadaan seperti saat ini tentu sangat menganggu kegiatan pariwisata, tidak hanya di Indonesia, namun di seluruh belahan dunia. Indonesia yang menjadikan pariwisata sebagai salah satu sektor utama dalam menunjang perekonomian negara 
harus mencari cara untuk segera keluar dari situasi sulit ini. Harapan mungkin akan didapatkan salah satunya melalui generasi Y atau generasi milenial. Menurut Putra (2016) generasi $\mathrm{Y}$ atau yang dikenal dengan sebutan generasi milenial merupakan generasi yang tumbuh pada era internet booming. Generasi ini fasih dalam menggunakan teknologi komunikasi instan seperti email, instant messaging dan social media seperti facebook, twitter, instagram, dan lainnya. Karakterisrik utama dari generasi ini adalah pola komunikasinya sangat terbuka dibanding generasi sebelumnya yaitu generasi $X$, dan tentu saja generasi milenial memiliki pengalaman dan wawasan yang lebih luas jika dibandingkan dengan generasi $\mathrm{Z}$ walaupun keduannya sama-sama memiliki kemampuan yang baik dalam mengadopsi teknologi baru (Prayoga,et al 2020), pemakai media sosial yang fanatik dan kehidupannya sangat terpengaruh dengan perkembangan teknologi, lebih terbuka dengan pandangan politik dan ekonomi, sehingga mereka terlihat sangat reaktif terhadap perubahan lingkungan yang terjadi di sekelilingnya, memiliki perhatian yang lebih terhadap keadaan finasialnya, di samping itu generasi ini cenderung kreatif dengan ide-ide baru.

Dengan segala keunggulan yang dimiliki, generasi milenial sangat di andalkan sebagai garda terdepan dalam memulihkan kondisi pariwisata melalui strategi promosi pariwisata yang lebih modern, sehingga para wisatawan akan jauh lebih tertarik untuk berkunjung ke Indonesia (Narendra, 2019). Beberapa bentuk aksi nyata telah dilakukan oleh pemerintah untukk menggerakan generasi milenial agar mengambil andil dalam mempromosikan pariwisata Indonesia ke seluruh belahan dunia. Salah satu bentuk nyata program kerja pemerintah melalui Kemenetrian Pariwisata adalah dengan membentuk Generasi Pesona Indonesia atau yang lebih dikenal dengan singkatan Genpi. Fungsinya adalah sebagai wadah generasi muda dalam turut serta melakukan promosi pariwisata dengan menciptakan produk-produk pariwisata baru yang menjanjikan, atau mengembangkan produk lama yang dikemas dengan konsep kreatif baru, guna meningkatkan value-added dari produk pariwisata tersebut sehingga lebih mudah untuk dipromosikan. Promosi merupakan salah satu jenis komunikasi yang sering dipakai oleh pemasar. Sebagai salah satu elemen bauran promosi, promosi penjualan merupakan unsur penting dalam kegiatan promosi produk Definisi promosi penjualan menurut American Marketing Association (AMA) adalah "Sales promotion is media and non media marketing pressure applied for a predetermined, limited period of time in order to stimulate trial, increase consumer demand, or improve product quality”. Hal ini menunjukkan bahwa promosi merupakan upaya pemasaran yang bersifat media dan non media untuk merangsang konsumen, meningkatkan permintaan dari konsumen atau untuk memperbaiki kualitas produk. Menurut Amali (2019) promosi merupakan salah satu variable dalam bauran pemasaran yang sangat penting dilaksanakan oleh perusahaan dalam memasarkan produk jasa. Kegiatan promosi bukan saja berfungsi sebagai alat komunikasi antara perusahaan dengan konsumen, melainkan juga sebagai alat untuk mempengaruhi konsumen dalam kegiatan pembelian atau penggunaan jasa sesuai dengan keinginan dan kebutuhannya. Promosi penjualan adalah bentuk persuasif langsung melalui penggunaan berbagai intensif yang dapat diatur untuk merangsang pembelian produk dengan segera atau meningkatkan jumlah 
barang yang dibeli pelanggan Sepak terjang generasi milenial dalam mempromosikan pariwsata, tidak lepas dari pengamatan media online, banyak media online mulai mengkritsi kinerja generasi milenial dalam mempromosikan pariwisata dengan kacamata serta sudut pandanganya masing-masing. Efektivitas kerja generasi milenial, terutama di tengah kondisi krisis pariwisata akibat pandemic Covid-19 seperti saat ini, tentu akan menjadi sorotan tajam dari berbagai media online.

Penelitian yang dilakukan untuk membedah framing media dalam melihat bagaimana pandangan media terhadap generasi milenial dalam melakukan promosi pariwisata di Indonesia belum pernah ada atau dilakukan sebelumnya sesuai dengan hasil observasi peneliti. Penelitian sebelumnya yang membahas tentang generasi milenial dilakukan oleh Gray, et al (2019) terkait peran milenial di lingkungan. Peneliti Andriyani, et al (2017), Yusniyawati dan Panuju (2020) meneliti tentang generasi milenial dalam sudut pandang politik dan Boer, et al (2020) tentang generasi milenial dan pemerintah dalam mengatasi Covid-19. Sementara penelitian yang menggunakan metode framing telah banyak dilakukan diantaranya penelitian yang dilakukan oleh oleh Ayu dan Pratiwi (2019) tentang kebijakan Top Up Uang Elektronik di Kompas.com, lalu penelitian yang dilakukan oleh Roosinda dan Alfraita, (2019) mengenai rekonsiliasi politik Jokowi-Prabowo.

Teori yang digunakan pada penelitian ini adalah teori konstruksi media massa yang dikemukakan oleh Berger dan Luckman. Teori ini memiliki beberapa asumsi dasar, yaitu: realitas yang ada diciptakan oleh manusia melalui kekuatan mengkonstruksi pada dunia sekitarnya, adanya hubungan antara pemikiran manusia dan konteks sosial yang berkembang dan dilembagakan, kehidupan masyarakat akan terus menerus dikonstruksi dan realitas merupakan kualitas di kenyataan masyarakat yang ada dan tidak bergantung pada seseorang (Zulaikha, 2019). Terdapat tiga hal yang dapat dianalisa dengan teori konstruksi media massa yaitu informasi yang sifatnya menyentuh banyak orang seperti persoalan yang sensitif mengandung unsur sensualitas dan kengerian. Hal yang sensitif merupakan persoalan yang sensitif yang meresahkan di masyarakat (Syahril, 2019). Media mengkonstruksi melalui pemberitaan yang muncul dengan pemilihan sudut pandang, penentuan sumber berita, dan mendefinisikan aktor serta adanya satu peristiwa. Bahasa menjadi unsur utama untuk menceritakan realitas, mengkonsep sesuatu dan menarasikannya sehingga ada nilai tertentu yang dipahami dan dimaknai (Damayanti et al 2016). Framing media dapat dimaknai sebagai cara bagaimana media menyajikan peristiwa, baik dilihat dari cara media menekankan bagian tertentu atau aspek tertentu suatu peristiwa, dan bagaimana cara media bercerita atas suatu realitas.

\section{METODE PENELITIAN}

Penelitian ini merupakan penelitian deksriptif kualitatif dengan metode analisis framing model Entman (Entman, 2007). Framing merupakan strategi membentuk dan menyederhanakan realitas, dengan cara menyeleksi, mengulangi dan menekankan 
aspek tertentu sehingga suatu peristiwa atau isu lebih menyita perhatian pembacanya (Eriyanto, 2008). Model framing Entman memiliki empat kategorisasi elemen yaitu: Define problems, Diagnose causes, Make moral judgement dan Treatment recommendation (Boer,et al, 2020). Define Problems merupakan tahapan dalam framing yang digunakan untuk menekankan bagaimana peristiwa dipahami oleh wartawan ketika muncul suatu permasalahan. Diagnose causes, sebuah tahapan analisis yang dilakukan untuk membingkai siapa yang dianggap sebagai aktor utama suatu peristiwa. Make moral judgment merupakan elemen framing yang digunakan untuk membenarkan argumentasi pada pendefinisian masalah yang sudah dibuat. Treatment recommendation digunakan untuk menilai solusi apa yang dipilih untuk menyelesaikan masalah. Penyelesaian tersebut sangat tergantung pada bagaimana peristiwa itu dilihat dan siapa yang dipandang sebagai penyebab masalah Penelitian ini mengeksplorasi proses framing media online dalam pemberitaan Generasi Milenial terkait promosi wisata selama pandemi covid-19 berdasarkan empat elemen analisis framing model Entman. Penelitian ini dilakukan untuk melihat bagaimana media online mempersepsikan kinerja generasi milenial, menggali aktor utama yang ditonjolkan dalam proses pemberitaan, penggunaan argumentasi yang digunakan dalam memperkuat pemberitaan dan menemukan solusi yang ditawarkan dalam upaya menyelesaikan permasalahan. Melalui keempat elemen analisis framing ini dapat menunjukkan keutuhan pembingkaian pemberitaan Generasi Milenial terkait promosi wisata selama pandemi covid-19.

Data penelitian diperoleh dari berbagai pemberitaan yang muncul di portal berita Putranababan.com, dan Pontianakpost.co.id. Media online Putranababan.com dipilih karena media ini secara intens memberikan atensi terhadap peningkatan pariwisata dari berbagai aspek, serta Putra Nababan sendiri merupakan jurnalis senior yang sudah berkiprah di bidang jurnalistik sejak 1992 hinga 2016, dengan berbagai penghargaan jurnalistik yang banyak diraih,, peneliti yakin mengenai kualitas pemberitaan yang diinformasikan oleh media online tersebut. Sementara Pontianakpost.co.id merupakan laman resmi media online masyarakat Provinsi Kalimantan Barat yang tentu saja peneliti yakin mengenai kredibilitas pemberitaan yang di informasikan. Data primer dalam penelitian ini adalah pemberitaan Generasi Milenial terkait promosi wisata selama pandemi covid-19, sedangkan data sekunder di penelitian ini adalah berbagai jurnal yang dapat dijadikan sebagai rujukan dalam proses analisis pemberitaan.

\section{HASIL DAN PEMBAHASAN}

Peneliti melakukan analisis terhadap berita di dua media online, yaitu: Putranababan.com, dan Pontianakpost.co.id dengan rincian berita sebagai berikut :

Tabel 1. Sampel Pemberitaan Generasi Milenial Terkait Promosi Wisata Sumber: Observasi Penulis 2020. 


\begin{tabular}{lll}
\hline Nomor & Judul Berita & Sumber \\
\hline 1. & $\begin{array}{l}\text { Promosi pariwisata membutuhkan peran } \\
\text { para generasi muda }\end{array}$ & $\begin{array}{l}\text { Putranababan.com } \\
(19 \text { Oktober 2020 })\end{array}$ \\
\hline 2. & $\begin{array}{l}\text { Promosi Pariwisata via Digital jadi } \\
\text { Pilihan }\end{array}$ & $\begin{array}{l}\text { Pontianakpost.co.id } \\
(\text { 07 September 2020) }\end{array}$ \\
\hline
\end{tabular}

Objek penelitian sejumlah dua pemberitaan Generasi Milenial terkait promosi wisata selama pandemi covid 19 di media online. Pada sajian dan analisa data terdapat empat pokok bahasan yaitu: define problem, causal interpretation, make moral judgement dan treatment recommendation. Pembingkaian berita dilakukan dengan mengamati judul berita, foto yang disajikan dan berapa kali nama pihak-pihak terkait disebut.

\section{Analisis Framing di putranababan.com}

Judul berita: "Promosi pariwisata membutuhkan peran para generasi muda" di putranababan.com

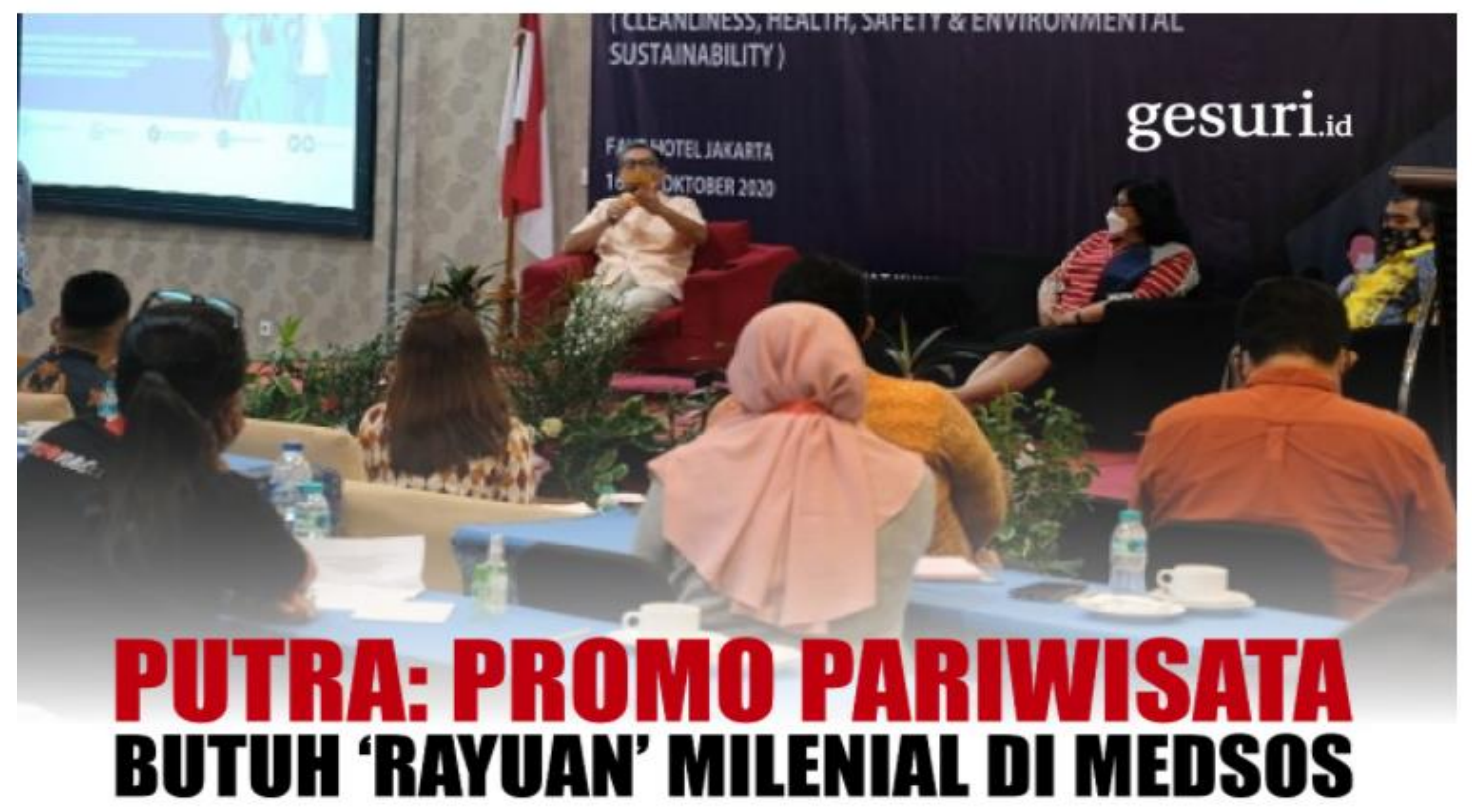

Gambar 1. Bimbingan Teknis bagi Generasi Milenial untuk menggalakan promosi wisata 
Define problem di dalam pemberitaan pada media online putranababan.com adalah pentingnya peran generasi milenial dalam mempromosikan pariwisata Indonesia, terlebih lagi di tengah kondisi pandemi covid-19 saat ini yang menyebabkan perekonomian Indonesia terganggu karena menurunnya aktivitas bisnis di sektor pariwisata. Namun kurang optimal atau maksimalnya marketing effort dari generasi milenial dalam mempromosikan pariwisata. Hal ini tercermin dari pernyataan yang disampaikan oleh Putra Nababan dalam Bimtek Penguatan Promosi Wisata Minat Khusus Melalui Media dengan Penerapan protokol C.H.S.E (Cleanliness, Health, Safety, and Environmental, Sustainability) yaitu "Jangan mudah patah arang dengan teknologi yang kalian punya. Ini soal kreativitas kita," Pernyataan ini menunjukkan bahwa di tengah kondisi covid-19 seperti saat ini generasi milenial harus tetap kreatif dalam menciptakan ide-ide promosi dengan memanfaatkan teknologi yang ada walaupun tengah berada ditengah kondisi yang mengharuskan semua pihak untuk mematuhi protokol kesehatan, salah satunya less-contact namun dengan menggunakan teknologi permasalahan ini seharusnya dapat diatasi.

Diagnose cause di dalam pemberitaan pada media online putranababan.com adalah di mana para generasi milenial saat ini belum mampu untuk mengoptimalkan potensi yang dimilikinya sehingga menyebabkan minimnya usaha-usaha dalam melakukan promosi pariwisata Indonesia di tengah pandemi covid-19. hal ini tercermin dalam pemberitaan media online putranababan.com melalui pernyataan sebagai berikut "Jangan sampai di sana tidak ada protokol kesehatan dan keamanannya. Wisatawan jadi gamang. Itulah perlu kreativitas adek-adek sekalian dengan menggunakan teknologi". Melalui kutipan pernyataan tersebut dapat disimpulkan bahwa media online mempersepsikan para generasi milenial harus mampu melakukan promosi yang tidak hanya sekedar memberikan janji-janji kepada konsumen atau calon wisatawan namun juga harus memberikan informasi yang sangat spesifik mengenai informasi produk pariwisata beserta protokol kesehatan yang memang telah menjadi syarat utama dalam melakukan aktivitas di era pandemi covid19 seperti saat ini. Permasalahan akibat kesenjangan antara promosi dengan kenyataan yang ada di lapangan, membuat wisatawan enggan untuk melakukan kunjungan kembali ke suatu daerah wisata. Rendahnya keinginan wisatawan untuk melakukan kunjungan kembali akan menyebabkan pada buruknya citra daerah wisata yang bersangkutan di mata masyarakat. Hilangnya kepercayaan wisatawan akan berpengaruh pada penurunan jumlah kunjungan. Menurut Ashari (2019) kepercayaan sebagai penilaian hubungan seseorang dengan orang lain yang akan melakukan transaksi tertentu sesuai dengan harapan dalam sebuah lingkungan yang penuh ketidakpastian. Kepercayaan merupakan aspek penting yang harus diciptakan oleh penyedia jasa wisata. Berdasarkan atas hal tersebut, pemerintah telah memberikan pernyataan sejak dini untuk melakukan promosi secara tepat. Generasi milenial harus memasarkan daerah wisata, sesuai dengan kondisi dan fasilitas yang diberikan.

Make moral judgment di dalam pemberitaan pada media online putranababan.com adalah banyak pihak yang sangat mengandalkan peran serta 
generasi milenial untuk ikut andil sebagai garda terdepan dalam mempromosikan pariwisata Indonesia dengan potensi yang mereka miliki serta pemanfaatan teknologi secara optimal. motivasi dan dukungan terus diberikan kepada generasi milenial. Salah satu bukti nyatanya adalah dengan pemberian bimbingan teknis (BIMTEK) yang telah dilakukan oleh Putra Nababan kepada generasi milenial. Bentuk dukungan dan motivasi dapat tercermin dari pernyataan "Promosi pariwisata sangat membutuhkan peran pada generasi muda untuk andil mempromosikan pariwisata Indonesia khususnya di Jakarta Timur" Dari pernyataan tersebut dapat disimpulkan bahwa pemberitaan media online putranababan.com menitikberatkan pada peran sentral generasi milenial untuk ikut ambil bagian dalam memulihkan industri pariwisata melalui promosi wisata yang baik, dalam artian bahwa promosi pariwisata harus disampaikan secara menarik dan juga dipertanggungjawabkan konten serta informasi yang terkandung di dalamnya seperti pernyataan yang ditekankan oleh Putra Nababan yaitu "semua promosi itu jangan merupakan rayuan gombal, sehingga perlu kemampuan merayu dengan catatan yang jelas protokolnya”. Nilai moral yang juga terkandung dalam pemberitaan ini adalah antara pemerintah dengan generasi milenial bergotong royong dalam mempromosikan pariwisata Indonesia. Hal ini daat dilihat dengan upaya yang dilakukan pemerintah dalam mengajak generasi milenial turut berperan aktif dalam melakukan promosi. Berbagai pelatihan dan pembekalan diberikan oleh pemerintah guna mencapai tujuan yang telah disepakati. Melalui partisipasi aktif dari kedua belah pihak, diharapkam daerah tujuan wisata mampu di promosikan dengan baik, namun tetap dengan melaksanakan protokol kesehatan.

Treatment recommendations di dalam pemberitaan pada media online putranababan.com adalah generasi milenial harus benar-benar memanfaatkan potensi yang dimiliki, mengingat sangat vital dan krusialnya peran generasi milenial di tengah kondisi seperti saat ini. Hal ini tercermin dari pernyataan yang muncul di pemberitaan pada media online putranababan.com yaitu "Hal itu, dilengkapi dengan kegetolan dan fasihnya para kawula muda tersebut dalam menggunakan media sosial namun dengan cara-cara yang kreatif”. Karakteristik generasi milenial yang sangat mudah dalam mengadopsi teknologi serta memiliki atensi yang tinggi terhadap perubahan lingkungan menjadi sebuah modal besar bagi generasi milenial untuk meningkatkan kompetensi sehingga dapat menjadi generasi yang bisa diandalkan guna memulihkan sektor industri pariwisata yang tentunya akan memiliki dampak yang besar terhadap pertumbuhan ekonomi di Indonesia. Sesuai dengan pernyataan yang dikemukakan pada penelitian Achmad et al, (2019) perilaku dan kebiasaan pada generasi milenial mempunyai tingkat antusiasme terhadap penggunaan teknologi cukup tinggi. Tingkat antusiasne yang tinggi salah satunya disebabkan oleh kemampuan adaptasi terhadap perubahan teknologi yang baik dari generasi milenial. Generasi Milenial cenderung berorientasi pada tugas, memiliki tujuan yang jelas serta kebiasaan kerja yang efisien, mengendalikan perasaan pribadi, bersikap objektif, menerima kritik dan saran, bertanggungjawab terhadap usaha pribadi dan menyesuaikan diri dengan situasi. Berdasarkan atas pernyataan tersebut, solusi yang ditawarkan oleh pemerintah dalam hal mempromosikan daerah wisata dengan memberdayakan generasi milenial melalui 
media sosial dinilai telah tepat.

Pemberitaan yang disampaikan oleh putranababan.com pada tanggal 19 Oktober 2020 lebih menitikberatkan pada potensi generasi milenial yang harus lebih ditingkatkan sebab generasi milenial dipersepsikan sebagai amunisi utama negara Indonesia untuk dapat pulih dan bangkit dari keterpurukan ekonomi yang terjadi seperti saat ini.

\section{Analisis Framing di pontianakpost.co.id}

Judul berita: "Promosi Pariwisata via Digital jadi Pilihan" pada pemberitaan media online pontianakpost.co.id

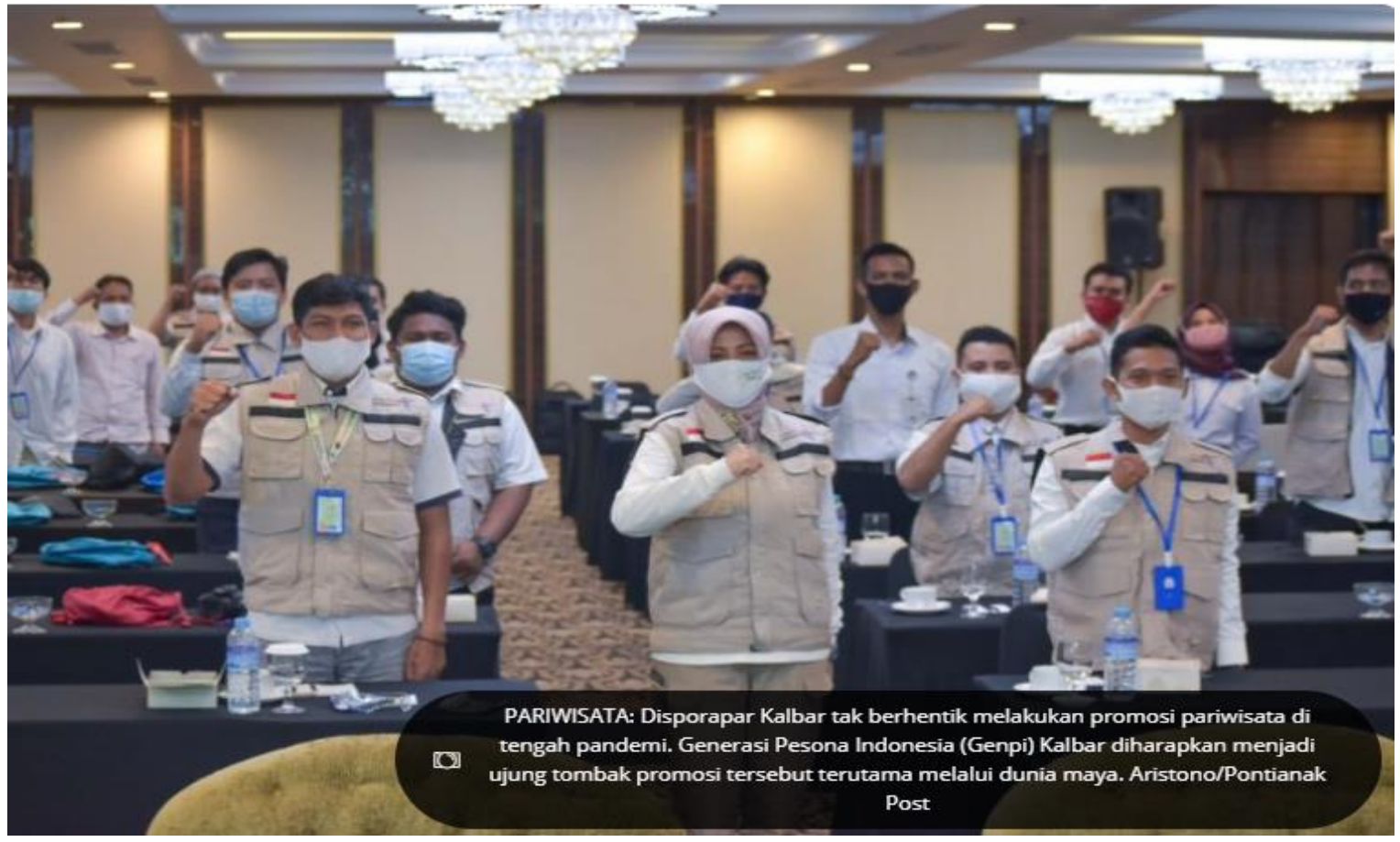

\section{Gambar 2. Pelatihan dan Pembinaan Generasi Pesona Indonesia (Genpi) Kalimantan Barat}

Define problem di dalam pemberitaan pada media online pontianakpost.co.id adalah berkembang pesatnya ilmu pengetahuan dan teknologi seharusnya menjadi sebuah peluang dalam mempromosikan pariwisata secara digital, terlebih lagi dengan kondisi pandemi covid-19 seperti saat ini. Namun generasi milenial yang menjadi tumpuan utama dalam strategi ini belum menunjukan kinerja yang baik. Hal ini diperkuat dengan pernyataan yang ada pada pemberitaan pontianakpost.co.id yaitu "Genpi merupakan gerakan yang diharapkan dapat meningkatkan minat anak muda dalam berkontribusi mempromosikan pariwisata di Kalimantan Barat. Untuk itu dipandang perlu Genpi diberikan Pembinaan dan penguatan”. Menurut kepala 
Disporapar provinsi Kalimantan Barat. Pandemi covid-19 memaksa seluruh pelaku pariwisata untuk mencari cara agar dapat meningkatkan kembali pendapatan dari sektor industri pariwisata.

Diagnose cause dalam pemberitaan media online pontianakpost.co.id yang berjudul "Promosi via digital jadi pilihan" adalah generasi pesona Indonesia atau yang disingkat Genpi merupakan wadah bagi generasi milenial untuk turut serta dalam mempromosikan pariwisata khususnya pariwisata di Kalimantan Barat melalui Genpi Kalbar, namun kinerja Genpi masih jauh dari maksimal sehingga dirasa perlu untuk menguatkan wadah tersebut sehingga bisa menjadi di ujung tombak dalam menghadapi tantangan baru setelah covid-19 yaitu era new normal. Hal ini diperkuat dengan pernyataan yang disampaikan kepala Disporapar Kalimantan Barat yaitu "Kita berharap dan mendorong agar kekuatan Genpi dimaksimalkan melalui media sosial atau platform lainnya Sehingga promosi dan daerah ini dikenal lebih luas."

Make moral judgment atau nilai moral yang diperoleh dari pemberitaan pontianakpost.co.id pada tanggal 07 September 2020 adalah Genpi sebagai wadah generasi milenial dapat menjadi agen perubahan dalam kondisi era new normal. Di samping menjadi duta dalam kampanye penerapan protokol kesehatan Genpi juga berperan dalam mempromosikan daerah wisata melalui media digital. Gerakan ini sekaligus diharapkan dapat meningkatkan minat dan kontribusi anak muda dalam mempromosikan daerah wisata. Hal ini sejalan dengan dua buah pernyataan yang disampaikan oleh Kepala Disporapar Provinsi Kalimantan Barat yaitu " Saat pembinaan ada praktek di lapangan. nah saya minta Genpi Kalbar tetap menerapkan protokol kesehatan dan segala aktivitas di objek wisata atau area publik menjadi duta kampanye protokol kesehatan pencegahan covid-19” Disamping itu pernyataan berikutnya adalah " kaum milenial sebagai agen perubahan kita minta terdepan dan apalagi di zaman kemajuan teknologi Kian pesat mereka harus terdepan” dari kutipan pernyataan tersebut dapat disimpulkan bahwa generasi milenial benar-benar sangat diandalkan oleh pemerintah Provinsi Kalimantan Barat sebagai ujung tombak utama dalam strategi promosi pariwisata di Kalimantan Barat.

Treatment recommendations di dalam pemberitaan pada media online pontianakpost.co.id adalah Pemerintah Kalimantan Barat melalui Kepala Disporapar Provinsi Kalimantan Barat memberikan pembekalan penguatan dan pelatihan bagi generasi milenial yang berada di dalam wadah Genpi Kalbar guna menjadi ujung tombak pemerintah Kalimantan Barat Dalam mempromosikan pariwisata daerahnya di tengah pandemi covid-19 melalui promosi secara digital. Hal ini sejalan dengan pernyataan dalam pemberitaan pontianakpost.co.id yaitu "Para pemuda khususnya anggota Genpi Kalbar dapat menjadi contoh yang baik bagi masyarakat dalam menerapkan praktik kesehatan sekaligus agen perubahan untuk terus berinovasi beradaptasi demi kemajuan di tengah pandemi covid-19”. Kepala Disporapar Provinsi Kalimantan Barat juga menambahkan pernyataaan bahwa "sebelum adanya wabah para wisatawan senang berpergian secara berbondong-bondong gua bahkan demi telah mengubah model tren pariwisata di mana masyarakat cenderung lebih memilih 
pergi dalam kelompok kecil" memalui pernyataan diatas dapat disimpulkan bahwa peran generasi milenial dalam menciptakan ide-ide baru guna menyesuaikan tren pariwisata sesuai dengan keadaan pandemi covid-19 sangat dibutuhkan dan pemerintah memberikan pelatihan serta penguatan guna meningkatkan kinerja dari generasi milenial yang terbentuk di dalam wadah yang bernama Genpi atau generasi pesona Indonesia wilayah Kalimantan Barat.

Dari kedua pemberitaan media online putranababan.com dan juga pontianakpost.co.id dapat disimpulkan bahwa kedua media online sama-sama memposisikan generasi milenial sebagai Garda terdepan atau ujung tombak dalam meningkatkan pariwisata yang terpuruk karena pandemi covid-19. kedua media tersebut juga memiliki framing yang sama bahwa kinerja generasi milenial saat ini sangat jauh dari optimal bahkan dipersepsikan usaha-usaha yang dilakukan oleh generasi milenial sangat minim dan belum memberikan dampak yang signifikan terhadap promosi pariwisata. putranababan.com lebih menyoroti mengenai kemampuan generasi milenial agar dapat memberikan informasi yang valid dari usahausaha promosi mengenai pariwisata, sedangkan pontianakpost.co.id melihat bahwa dengan keunggulan karakteristik generasi milenial yang mereka miliki yaitu sangat mudah dalam mengadaptasi teknologi sudah seharusnya para generasi milenial bisa memanfaatkan teknologi secara maksimal Sehingga dalam melakukan promosi pariwisata semuanya dapat dilakukan secara efektif dan efisien.

Framing media merupakan salah satu usaha untuk mengkritisi kiprah generasi milenial di tengah kondisi yang sulit seperti saat ini. Oleh karenanya, pembingkaian generasi milenial sebagai sumber berita merupakan suatu usaha untuk menunjukkan dukungan atas keseriusan dari generasi milenial dalam menjadi garda terdepan guna mempromosikan pariwisata yang tengah terpuruk seperti saat ini., media berita online juga memegang peranan penting guna menginformasikan, mengedukasi dan memberikan motivasi serta harapan kepada masyarakat melalui kinerja generasi milenial kedepannya.

\section{SIMPULAN}

Berdasarkan hasil analisis framing dalam pemberitaan media online putranababan.com dan pontianakpost.co.id dapat ditarik sebuah kesimpulan bahwa peran media online tidak sebatas sebagai penyampai informasi. Pada era seperti saat ini sangat dibutuhkan media online yang mampu menjalankan fungsi pengawasan serta mengkritisi setiap fenomena baru di tengah situasi yang tidak biasa seperti saat pandemi covid-19 ini. Hasil penelitian ini menunjukan bahwa media online putranababan.com dan pontianakpost.co.id memberikan perhatian pada usaha-usaha pemerintah dalam penguatan generasi milenial guna menjadi garda terdepan dalam mempromosikan pariwisata di Indonesia. Hasil penelitian ini juga menunjukan beberapa hal penting diantaranya adalah Define problem yaitu belum optimalnya peran generasi milenial sebagai ujung tombak dalam promosi pariwisata di Indonesia. 
Diagnose cause yaitu belum optimalnya peran generasi milenial akan menyebabkan industri pariwisata kian lesu dan tidak dapat bangkit dari keterpurukaan keadaan saat pandemi covid-19. Make moral judgment dimana pihak pemerintah berusaha memberikan pelatihan-pelatihan serta penguatan guna mempertegas peran dan fungsi generasi milenial sebagai ujung tombak di dalam promosi pariwisata di Indonesia. Treatment recommendations yaitu penting bagi semua pihak untuk mendukung penuh generasi milenial dalam mempromosikan pariwisata, kemampuan dari karakteristik generasi milenial yang sangat mudah mengadopsi teknologi baru, diharapakan dapat mempermudah generasi milenial dalam memaksimalkan setiap peluang guna mempromosikan wisata Indonesia ke seluruh pelosok dunia di era new normal. Simpulan diatas menunjukan bagaimana media online mengkonstruksi makna dalam setiap elemen-elemen beritanya. Media memiliki sudut pandangnya masing-masing atas fenomena sosial yang terjadi, dalam artian media online dalam mengkritisi fenomena tersebut tentu menggunakan metode yang berbeda-beda. Melalui temuan penelitian ini diharapkan media online mampu membantu pemerintah sebagai perpanjangan tangan menyampaikan pesan-pesan dan juga pemberitaan positif dan membangun sehingga mampu tetap menumbuhkan optimisme masyarkat untuk dapat melewati permasalahan yang timbul di masa pandemi Covid-19 dan turut serta memberikan dukungan motivasi kepada generasi milenial agar mampu untuk memainkan perannya guna mengembalikan industri pariwisata di Indonesia sebagai salah satu daya saing bangsa melalui promosi wisata yang berbasis pada teknologi digital. 


\section{Referensi}

Achmad R Willya W, Marcelino Vincentius Poluakan, Didin Dikayuana, Herry Wibowo dan Santoso Tri Raharjo. Potret Generasi Milenial Pada Era Revolusi Industri 4.0. Jurnal Pekerjaan Sosial. ISSN: 2620-3367 Vol. 2 No: 2 pp: 187 197

Alodokter.com.2020. https://www.alodokter.com/virus-corona. Diakses pada tanggal 28 Oktober 2020.

Amali, M. T. (2019). Pengaruh Terpaan Iklan Online dan Kelompok Referensi Terhadap Perilaku Adopsi Go-Jek di Kota Semarang yang Dimediasi oleh Sikap Konsumen. Jurnal Audience, 2(1).

Andriyani, T., Zahra, S., \& Swasti, D. D. (2017). Gambaran Pola Identifikasi Generasi Milenial dalam Memilih Tokoh Politik Melalui Media Sosial. Jurnal Ilmiah Penelitian Psikologi, 3(2), 69-81

Ashari, Muhammad.2019. Jurnalisme Digital: Dari Pengumpulan Informasi Sampai Penyebaran Pesan. Jurnal Komunikasi. P-ISSN: 25483749 E-ISSN: 26154420. Vol 4, No 1. Pp 1-16

Ayu, D., \& Pratiwi, M. R. 2019. Agenda Media dalam Pemberitaan Top Up Uang Elektronik di Media Online Kompas.Com. Widya Komunika, 9(1), 86104.

Boer, Kheyene Molekandella, Mutia Rahmi Pratiwi, dan Nalal Muna. 2020."Analisis Framing Pemberitaan Generasi Milenial dan Pemerintah Terkait Covid-19 di Media Online." Communicatus: Jurnal Ilmu komunikasi 4.1.pp.85-104.

Damayanti, S., Mayangsari, I. D., \& Putra, D. K. S. 2016. Analisis Framing Robert N. Entman atas Pemberitaan Reklamasi Teluk Jakarta di Majalah Tempo. eProceeding of Management : Vol.3, No.3 December 2016 | Page 3928. ISSN : 2355-9357

Entman, R. M. (2007). Framing Bias: Media in the Distribution of Power. Journal of Communication, 57(1), 163-173. doi:10.1111/j.1460-2466.2006.00336.x

Eriyanto. (2008). Analisis Framing ; Konstruksi, Ideologi, dan Politik Media Yogyakarta: LKiS

Gray, S. G., Raimi, K. T., Wilson, R., \& Arvai, J. (2019). Will Millennials save the world? The effect of age and generational differences on environmental concern. J Environ Manage, 242, 394-402. doi:10.1016/j.jenvman.2019.04.071

Narendra, Asnurul Novia, Habsari , Sri Kusuma, dan Ardianto , Deny Tri. 2019. Kepemilikan Serta Pembentukan Modal Sosial Oleh Wisatawan Dalam Memilih House Of Sampoerna Sebagai Daya Tarik Wisata. Jurnal Pariwisata Pesona. Volume 04 No 1, Juni 2019: p 67-80.

Nasional.kontan.co.id.2020. https://nasional.kontan.co.id/news/menparekraftargetkan-peringkat-pariwisata-indonesia-naik-ke-posisi-36-tahun-2021.

Diakses pada tanggal 21 Oktober 2020.

Pikiran.rakyat.com.2020.https://www.pikiranrakyat.com/nasional/pr01341188/fixriau pesisir.pikiran-rakyat.com. Diakses pada tanggal 20 Oktober 2020.

Pontianakpost.co.id.2020.https://pontianakpost.co.id/promosi-pariwisata-via-digital- 
jadi-pilihan/. Diakses pada tanggal 23 Oktober 2020.

Prayoga, I Made Surya, Adiyadnya, Made Santana Putra dan Putra , Bagus Nyoman Kusuma.2020. Green Awareness Effect on Consumers' Purchasing Decision. Asia-Pacific Management and Business Application Vol.8 no (3). pp 199-208

Putra, Adetiya Prananda, Wijayanti, Tantri dan Prasetyo, Jimmi Sandi. 2017. Analisis Dampak Berganda (Multiplier Effect) Objek Wisata Pantai Watu Dodol Banyuwangi. Journal of Tourism and Creativity. Vol.1 No.2 Juli 2017. ISSN: 2549-483X. pp 141-154.

Putra, Yanuar Suya.2016. Theoretical Review: Generational Difference Theory. Among Makarti 9(18) : 123134.

Putranababan.com.2020. https://putranababan.com/quote/619/promosi-pariwisatamembutuhkan-peran-para-generasi-muda. Diakses pada tanggal 24 Oktober 2020.

Roosinda, F. W., \& Alfraita, A. 2019. Rekonsiliasi joko widodo dan prabowo subianto pasca pemilu 2019 dalam pemberitaan detik.com, cnnindonesia.com dan viva.co.id periode 13-27 juli 2019. Jurnal Kajian Media, 3(2).

Sugihamretha, I Dewa Gde. 2020. Respon Kebijakan: Mitigasi Dampak Wabah Covid19 Pada Sektor Pariwisata. The Indonesian Journal of Development Planning Volume IV No. 2 - Juni 2020. Pp 191-206

Syahril, R., \& Meliala, R. M. 2019. Pengaruh Terpaan Media Terhadap Minat Masyarakat Mengikuti Ajang Pencarian Bakat Indonesia Idol (Studi Peserta Audisi Di Jakarta). Jurnal AKRAB JUARA, 4(4).

Yusniyawati, E., \& Panuju, R .2020. Karakteristik Ekspektasi Generasi Milenial Calon Walikota Surabaya 2020-2025: Peduli dan Merakyat. Calathu: Jurnal Ilmu Komunikasi, 2(1), 10-19.

Zulaikha, N.H. .2019. Analisis Framing Pemberitaan Pilgub Jawa Timur 2018 pada Situs Berita Daring Indonesia. Communicatus: Jurnal Ilmu Komunikasi, 3(1), 91-110. 